\title{
The media system
}

The growth of 'semi-democracies' across the world, where elections are held but are rigged by state power-holders, has brought into ever-sharper focus how much a country's media system conditions the quality of its democracy. Free elections without some form of media diversity and balance clearly cannot hope to deliver effective liberal democracy. Ros Taylor and the Democratic Audit team look at how well the UK's media system operates to support or damage democratic politics, and to ensure a full and effective representation of citizens' political views and interests.

\section{What does liberal democracy require of a media system?}

The media system should be diverse and pluralistic, including different media types, operating under varied systems of regulation, designed to foster free competition for audiences and attention, and a strong accountability of media producers to citizens and public opinion.

$\downarrow$ Taken as a whole, the regulatory set-up should guard against the distortions of competition introduced by media monopolies or oligopolies (dominance of information/content 'markets' by two or three owners or firms), and against any state direction of the media.

A free press is a key part of media pluralism - that is, privately owned newspapers, with free entry by competitors and only normal forms of business regulation (those common to any industry) by government and the law.

Because of network effects, state control of bandwidth, and the salience of TV/radio for citizens' political information, a degree of 'special' regulation of broadcasters to ensure bipartisan or neutral coverage and balance is desirable, especially in election campaign periods. However, regulation of broadcasters must always be handled at arm's length from control by politicians or state officials, by an impartial quasi-nongovernmental organisation (quango) with a diverse board and professional staffs.

Where government funds a state broadcaster (like the BBC), this should also be set up at arm's length, and with a quango governance structure. Government ministers and top civil servants should avoid forms of intervention that might seem 
to compromise the state broadcaster's independence in generating political, public policy or other news and commentary.

Journalistic professionalism is an important component of a healthy media system, and the internalisation of respect for the public interest and operation of a 'reputational economy' within the profession provide important safeguards against excesses, and an incentive for innovation. Systems that strengthen occupational self-regulation within the press are valuable.

The overall media system should provide citizens with political information, evidence and commentary about public policy choices that are easy to access, at no or low cost. The system should operate as transparently as possible, so that truthful/factual content predominates, it quickly 'drives out' incorrect content and 'fake news', and that 'passing off' and other lapses are minimised and rapidly counteracted.

People are entitled to published corrections and effective redress against any reporting that is unfair, incorrect or invades personal and family privacy. Citizens are entitled to expect that media organisations will respect all laws applying to them, and will not be able to exploit their power to deter investigations or prosecutions by the police or prosecutors.

Public interest defences should be available to journalists commenting on possible political, state and corporate wrongdoing, and media organisations should enjoy some legal and judicial protection against attempts to harass, intimidate or penalise them by large and powerful corporations, or by the state.

At election times especially, the media system should inform the electorate accurately about the competing party manifestos and campaigns, and encourage citizens' democratic participation.

The UK has long maintained one of the best developed systems for media pluralism amongst liberal democracies, centring on five components:

(i) A free press, one that is privately owned and regulated only by normal business regulations and civil and criminal law provisions. The biggest UK newspapers are highly national in their readership and coverage. They characteristically adopt strong political alignments to one party or another. A voluntary self-regulation scheme has provided only a weak code of conduct and system of redress in the event of mistakes in reporting or commentary.

(ii) A publicly owned broadcaster (the BBC), operated by a quasi-non-governmental agency (quango), at arm's length from any political control by the state or politicians. It is regulated by another arm's length quango, Ofcom, so as to be politically impartial in its coverage, according space to different parties and viewpoints.

(iii) A few private sector broadcasters whose political coverage is regulated by the same set of rules to be politically impartial - which are also set and enforced by Ofcom, insulated from control by politicians, the state and from the broadcasters themselves. 
(iv) Strongly developed journalistic professionalism, with common standards of reporting accuracy, and much looser agreement on fairness in commentary and respect for privacy, shared across (almost) the whole occupational group. But breaches are enforced only informally by weak social sanctions, such as disapproval or reputational damage for offenders within the profession.

(v) Social media, which are an increasingly salient aspect of the media system, and resemble the free press in being unregulated beyond normal legal provisions. The biggest online sites and associated social media are journalistically produced by newspapers, and generally operate on the same lines, although with less political colouration of news priorities. However, much politically relevant content is also generated by a wide range of non-government organisations (NGOs), pressure groups and individuals, many of whom are strongly politically aligned and may not feel bound by journalistic standards. (See Chapter $\mathbf{3 . 4}$ for a detailed discussion of social media.)

\section{Recent developments}

In recent years, the UK's media landscape has undergone enormous transformation. Not only has news consumption shifted online, but the growth in digital social media has enabled people to originate, find and share information in ways that challenge the traditional hegemony of state-funded broadcasters and the national press.

The biggest source of concern about the democratic qualities of the UK's media system has been that most of the press perennially back the Conservative Party (in very forceful ways in most cases). Far fewer papers normally back Labour, and the Liberal Democrats receive only episodic support from smaller papers. Once predicted to become just another depoliticised operation of conglomerate corporations, in fact newspapers are still run in a hands-on, 'press baron' fashion by powerful companies or media magnates (like Rupert Murdoch and the Barclay brothers). Figure 1 shows that the fiercely anti-Labour and proBrexit Sun is by far the biggest newspaper, and Rupert Murdoch also owns the Times/ Sunday Times. The Daily Mail, Daily Express and Daily Telegraph complete the Tory press hegemony. The Labour-backing Trinity Group newspapers (owning the Daily Mirror, Daily Record, and The People) have smaller readerships, as does the Guardian. Some papers also take a neutral or more varied political line. 
Figure 1: The percentage of UK respondents who used different TV, radio and print news sources in 2017 - and the political affiliations of these sources

\begin{tabular}{|c|c|c|c|}
\hline Source & Political stance & $\begin{array}{l}\% \text { used } \\
\text { in last } 3 \\
\text { days }\end{array}$ & $\begin{array}{l}\% \text { used } \\
\text { in last } \\
\text { week }\end{array}$ \\
\hline BBC News (TV \& radio) & Regulated non-partisan & 53 & 64 \\
\hline ITV News & Regulated non-partisan & 20 & 33 \\
\hline Sky News & Regulated non-partisan & 14 & 21 \\
\hline Sun (\& Sunday Sun) & Conservative, Brexiteer & 7 & 15 \\
\hline Daily Mail (\& Sunday) & Conservative, Brexiteer* & 8 & 13 \\
\hline Metro (free) & Non-political & 6 & 11 \\
\hline Regional or local newspapers & Varied & 4 & 11 \\
\hline Daily Mirror (SM, Daily Record) & Labour, EU pragmatic & 6 & 10 \\
\hline Channel 4 News & Regulated non-partisan & 4 & 10 \\
\hline Commercial radio news & Regulated non-partisan & 7 & 10 \\
\hline Times/Sunday Times & Conservative, EU pragmatic & 3 & 7 \\
\hline Guardian/ Observer & Labour, Remainer & 2 & 5 \\
\hline London Evening Standard (free) & Conservative, Remainer & 2 & 4 \\
\hline Daily Telegraph (\& Sunday) & Conservative, Brexiteer & 2 & 4 \\
\hline 'l’ (newspaper) & Independent, Remainer & 2 & 4 \\
\hline CNN & Regulated non-partisan & 1 & 4 \\
\hline Daily Express (\& Sunday) & Conservative, Brexiteer & 1 & 2 \\
\hline \multirow{4}{*}{ Political orientation of source } & Regulated non-partisan & 99 & 142 \\
\hline & Conservative & 24 & 47 \\
\hline & Labour & 8 & 15 \\
\hline & Independent, non-political press & 8 & 15 \\
\hline \multirow{3}{*}{ Brexit orientation of source } & Brexiteer & 18 & 34 \\
\hline & Neutral or EU pragmatic & 105 & 153 \\
\hline & Remainer & 4 & 9 \\
\hline
\end{tabular}

Source: Data from Reuters Institute Digital News Report 2018 (Express from full survey data supplied). Classifications of political orientations by the authors.

Note: Percentages sum to more than $100 \%$ because people use multiple media sources. *The Daily Mail was strongly pro-Brexit, but the Mail on Sunday supported Remain. 
However, Figure 1 also shows that in terms of media exposure the non-partisan broadcast news media have maintained far more reach and regular use than print newspapers. In modern times a trio of TV news outlets (BBC, ITV and Sky News) plus radio have provided much of people's political information. All broadcasters operate under political neutrality rules that apply with special force during election campaigns. They must achieve a bipartisan balancing of Conservative and Labour issues and viewpoints (given their historic dominance in shaping general election voting) plus the broadly proportional representation of other parties - for example, giving the SNP in Scotland equal prominence. Optimists about the media system would point out that in Figure 1 four times as many people have used non-partisan media than have read Conservative-aligned newspapers. Similarly, more than five times as many people have used sources that take a neutral or pragmatic view of Brexit than have used strongly pro-Brexit sources. Figure 1 also shows that most people use multiple media sources and thus are exposed to a mix of partisan and non-partisan coverage of issues and politics.

However, newspaper-run websites now provide major sources of revenue for the press, and they compete for online attention with the broadcasters' websites and online-only publications. Figure 2 shows that the papers' online readership produces a greater balancing of political alignments in the digital world. During the 2015 and 2017 election campaigns Labour enjoyed the backing of the Guardian website, which has a much bigger reach than its print version. The Daily Mirror is also prominent. On the Tory side the Daily Mail is the leading online title, along with the Telegraph.

Figure 2: The online monthly readership of UK newspaper websites (in 2017)

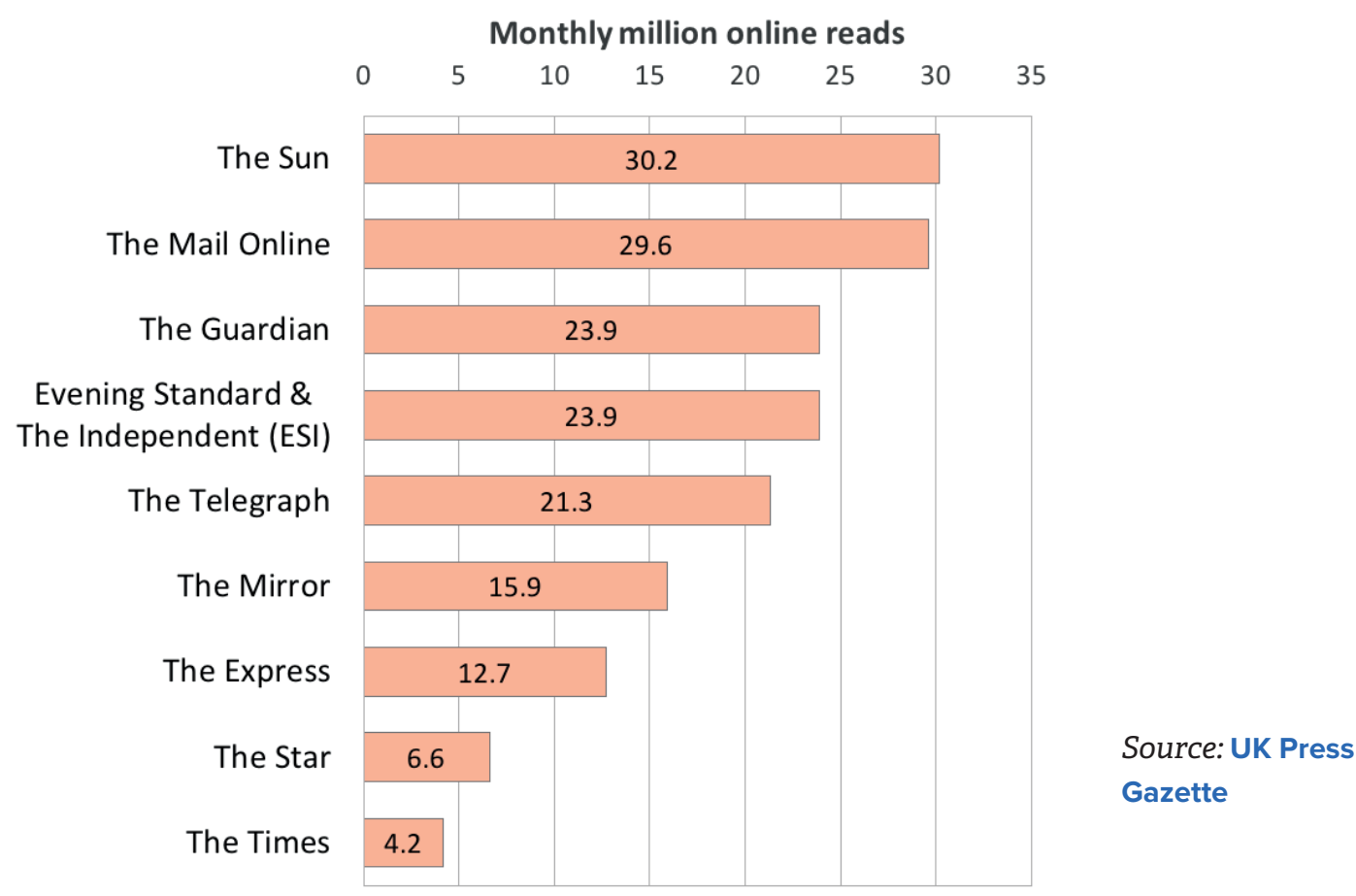


These modifying factors perhaps have begun to blunt the 'power of the press' compared with (say) the 1992 general election, when Murdoch's leading title boasted 'It was the Sun wot won it' for John Major. In 2017, the Sun's election day 'Cor-Bin' front page was no less strident in denouncing Jeremy Corbyn. On the day before polling, the Daily Mail devoted 13 pages to anti-Corbyn and anti-Labour stories and commentary, with the cover headline 'Apologists for Terror'). The levels of political bias exhibited can also be strikingly unconstrained, verging into 'fake news' generation, with, for example, the front pages of the Sun and Daily Mail both explicitly linking top opposition politicians to terrorist threats.

Yet optimists about the media system point out that Corbyn's Labour surged in popularity during the campaign, and forced a hung parliament, despite facing a wall of Tory press criticism. Perhaps, then, media diversity is working after all, allowing voters to form their own opinions from a range of different sources?

\section{Strengths, Weaknesses, Opportunities, Threats (SWOT) analysis}

\section{Current strengths}

Figures 1 and 2 demonstrate that the UK's media system remains essentially pluralistic when taken as a whole, especially in the complementary nature of a free press offset by bipartisan regulated broadcasting.
The growth of satellite and online TV channels, and rapid increases in the numbers of specialised or paid-for TV channels (many catering for niche interests) has reduced the ways in which TV presents a common news agenda to all citizens. Yet the BBC, ITV, Channel 4 and Sky News still compete very effectively for news and politics audiences (Figure 1). Although its audience is ageing somewhat, the BBC's broadcast news coverage continues to reach two-thirds of the public each week.

\section{Current weaknesses}

The print versions of the leading national newspapers remain wedded to highly partisan approaches to covering UK politics and elections. Cross-ownership of titles and broadcasting by powerful and committed corporate leaders actively trying to sway elections and policy decisions (like Rupert Murdoch) perennially distorts political power away from political equality. Traditional forms of joint agenda-setting by journalists ('wolf pack' questioning on top issues) and new developments (for example, press preview programmes on 24-hour TV and press front pages on broadcaster websites) mean that press distortions can drag public service broadcasters into line with a press-led agenda.

\section{Press coverage of the 2016 EU referendum} campaign was frequently hyper-partisan, disingenuous or actively misleading (as in claims that Turkey was poised to join the EU). If and when such claims were ever corrected at a media regulator's request, this happened only after readers had voted. 


\section{Current strengths}

The mainstream press has experimented with subscription models that offer an alternative to paywalls, such as voluntary subscriptions or one-off donations and crowd-funded journalism.

\section{Current weaknesses}

The public's reluctance to pay for news, both online and offline, as well as declining advertising revenues and insurgent start-ups, represent an existential threat to established press brands and perhaps other media. The local press is also in decline, with far fewer reporters. Those who remain are sometimes based outside their 'beat' and discouraged from original reporting for reasons of time and cost.

Several new versions of self-regulation have emerged, with Impress and Ipso offering different models (see below). The closure of the News of the World over its toxic phonehacking culture still looms large in editors' and journalists' consciousness.

The Freedom of Information Act, a key right for citizens that is also a valuable tool for journalists, has survived repeated threats due to Whitehall cost-cutting and politicians' hostility to it.

Parliamentary reporting has adapted to the live blog format, arguably providing a more detailed and real-time account of proceedings than the legacy print media did.
The newspaper industry has failed to reach consensus on press regulation after the hacking scandal and Leveson report, including on the chilling effect of section 40 of Crime and Courts Act (see below). Complaints mechanisms are often weak and unclear, especially among new entrants.

Court injunctions to force the press to respect people's privacy are the preserve of the very wealthy, though are now declining in numbers. Ordinary citizens typically find it hard to achieve redress or corrections for mistakes from newspapers.

Coverage of Welsh politics is especially inadequate. The nation lacks a powerful home-grown media and the Welsh Assembly has considered appointing its own team of journalists to report proceedings. Like local authority-run newspapers, this is a problematic development.

\section{Current opportunities}

Libel cases have fallen since the Defamation Act 2013 simplified the public interest defence. If the trend is maintained, this may enable more adventurous investigatory reporting in future.

\section{Current threats}

Mainstream media and journalists are increasingly distrusted by the public, particularly on the left, for their perceived biases and remoteness from 'ordinary people'. 


\section{Current opportunities}

Citizens have mobilised on social media to counteract newspaper partisan or commentary excesses - for example, Stop Funding Hate's campaign to shame big advertisers into boycotting newspapers accused of anti-Islam coverage and stirring up racial hatred. As online sources grow more salient, so a somewhat less partisan style of political journalism may take root. Crowd-funded initiatives like WikiTribune may have the potential to make the ownership and administration of media outlets more transparent and accountable to their readers.

Recognising the dearth of local news reporting, some efforts are being made to fund and train reporters (see below).

Hyperlocal news models continue to evolve, with the ease of making micropayments offering the possibility of an (albeit unpredictable) revenue stream (see Chapter 3.4 on social media).

\section{Current threats}

Both 'alt-left' and 'alt-right' media outlets, run directly by political interest groups seeking to manipulate public debates, have already penetrated the UK market. They have often used 'data-industrial complex' methods to target sets of swing citizens, and paid-for Facebook and Twitter 'news' generation to evade journalistic controls or scrutiny. The alt-left (for example, the Canary and Evolve Politics) claimed extensive influence in the 2017 general election, while the alt-right (and possibly Russian intelligence) seems to have helped sway the EU referendum campaign towards 'Leave'.

Official proposals for a modernised Espionage Act could threaten whistleblowers and introduce a further chilling effect to journalists' ability to pursue stories relating to the 'secret state'.

The declining sales of local newspapers, and the closure of many titles, plus the relative weakness of regional and local broadcasting within the BBC and ITV, have all meant that journalistic coverage of local politics has drastically fallen away. Court reporting is also in steep decline.

\section{The BBC and Sky}

The regulated TV broadcasters (and in the BBC's case, state-funded too) have been a key part of the UK's media system since the BBC was set up in the 1920s. Their role enjoys a wide amount of cross-party consensus, but the Tory press has constantly accused the BBC of having a 'left-wing' and liberal causes bias. Conversely, in 2015-17, when Jeremy Corbyn's Labour leadership was controversial, some 'alt-left' outlets attacked the BBC (and in particular its political editor, Laura Kuenssberg) for bias against him. The BBC is now externally regulated by Ofcom, putting it on a par with other regulated broadcasters, instead of the previous exceptional situation where the BBC Trust was both 'judge and jury' on major complaints. The BBC's once very extensive online web presence has also been greatly cut back to focus on news and programme-specific sites, chiefly as a result of commercial rivals complaining to Ofcom that it was 'crowding out' their own web operations.

A Conservative government green paper in 2015 raised the possibility of cutting or reforming the BBC's licence fee (a disliked tax on TVs) and cutting back the corporation's 
remit to focus on news. However, the charter renewal of January 2017 guaranteed the licence fee's survival for at least 11 years, with inflation-linked increases until early 2022. A new BBC Board - no more than half of whose members are government appointees - was put in place to manage the Corporation. The National Audit Office will now play a role in scrutinising BBC spending.

The BBC also undertook to serve ethnic minority and regional audiences better. The BBC Trust previously found that audiences in the devolved regions felt the corporation needed to do more to hold their politicians to account, particularly in Wales, where Cardiff University's 2016 Welsh Election Study identified a 'democratic deficit' in media. In Scotland SNP supporters have regularly argued that the BBC is pro-union and called for a separate Scottish Broadcasting Corporation to be set up. Across the UK, the reach of BBC services is falling as its radio and TV audience ages.

The Brexit referendum campaign represented a major challenge for all the UK media, but particularly so for the BBC's public service remit and due impartiality. The subject matter was complex and the public was poorly informed about the history and functions of the EU. The BBC's referendum guidelines sought to give 'due weight' and prominence to all the main strands of argument and to all the main parties, rather than being an overly simplistic 'seesaw' approach to impartiality - the latter critiqued by Jay Rosen as 'views from nowhere'. Despite these efforts, the BBC was criticised for inadequate scrutiny of campaign claims on both sides and faced particular opprobrium from Leave-supporting politicians and newspapers. After the vote criticism continued from both Leavers and Remainers.

At the height of the News of the World phone hacking scandal, the Murdoch-run 21st Century Fox (the ultimate owner of the Sun and the News of the World) withdrew a bid to assume full control of Sky that had previously seemed likely to succeed. After an interregnum, the bid was renewed and Ofcom was lobbied to block it on the grounds that Murdoch's companies failed a 'fit and proper' persons test. Ofcom did not agree and let it continue, but the issue was referred by the minister to the Competition and Mergers Authority. Their initial findings in January 2018 said that the merger was not in the public interest because of media plurality concerns. In July 2018, 21st Century Fox successfully bid for Sky, on condition that Sky News was divested to a buyer that will fund it for a decade and guarantee its independence.

This bidding war also reflected a new and salient challenge to the established broadcasters (and Hollywood film studios) posed by new media players Amazon, Netflix and some similar competitors focusing on paid-for, on-demand streaming of drama and entertainment only, paralleling the earlier growth of sports and specialist channels. As millions of consumers migrate to these services, so the audiences for regular bipartisan TV news may be eroded - because fewer people are following TV services offering a mix of services with regular slots for news.

\section{Newspaper closures and online paywalls}

For the 'free press' across the UK, the viability of newspaper titles is crucial. With sales and advertising revenue falling, the Independent newspaper ceased all print editions to 
become online only, and subsequently reported a return to profit. The Times and Financial Times continued to maintain online paywalls to fund their journalism, with the Telegraph also erecting a partial paywall. The London Evening Standard became a free paper in 2009 , maintaining its circulation. However, only $3 \%$ of Britons have an online news subscription, one of the lowest percentages across the European Union. At Murdoch's insistence, The Sun experimented with a paywall in 2013, but abandoned it two years later as its online readership numbers fell. A majority of readers seem unwilling to pay for online news when it is freely available elsewhere. However, the Guardian reports 500,000 regular paying supporters and a further 300,000 one-off contributors.

Regional papers in big cities outside London, and local publications across the country, also experienced a drop of 12\% in digital and print revenues in 2015-16. Across the UK 198 local papers closed in 2005-16, plus 40 more in 2017. Falling advertising revenues have been the principal driver of local journalism's decline, but not the only one. More people have been renting privately and moving between local areas. The sociologist Anthony Giddens argued that social life has become 'dis-embedded' from the local level, so that 'we cannot take the existence of local journalism for granted'. The decline in local reporting was exemplified in tragic fashion by the failure of west London's press to pick up on the repeatedly expressed concerns of the Grenfell Tower residents on the Grenfell Action Group blog about the safety of their building, before it burnt down, killing 72 people in June 2017.

Some efforts are being made to reinvigorate the sector. The BBC has earmarked £8m for 'local democracy reporters' from selected news services, giving them training and access to BBC video and audio. In addition, the local press decline has been a key catalyst for a growth of citizen-driven hyperlocal sites (see Chapter 3.4).

\section{Media ownership, partisanship and transparency}

A diversity of media ownership has historically been seen as important because of the strong political orientation of the national newspaper titles. But in addition, owning newspapers has often helped different capitalist interests to advance their own interests in regulatory matters and other public policy concerns, especially where press titles and broadcast channels are owned by the same mogul or firm. Elected politicians may want to keep powerful media owners onside and so give them the benefit of the doubt in regulatory decisions.

Ownership of the major newspapers has long been divided among a few large companies, with the American-owned News Corp, publisher of the Sun and the Times/Sunday Times, as the dominant player. These, along with the Daily Mail (DMG Media), the Daily Express (bought by Trinity Mirror in 2018) and the Telegraph Media Group, continue to dominate right-leaning coverage, while the Mirror, the Guardian and the Independent occupy the left or centre. Pearson sold the Financial Times to the Japanese company Nikkei in 2015. A Saudi investor, Sultan Muhammad Abuljadayel, took a stake of between 25\% and 50\% in the Independent's holding company in 2017, causing concern among some of its journalists, although they were assured its editorial independence would remain intact. 
However, online media has inflicted considerable disruption on the newspaper-dominated press model. Digital entrants have used social media to disseminate free news and opinion. Some originate in the US (BuzzFeed, the Huffington Post, Vice), others are funded by the Russian state (Russia Today and the Edinburgh-based Sputnik). A number of hyper-partisan low-cost start-ups - such as Evolve Politics and the Canary, a free-to-access site funded by advertising and voluntary subscriptions - have generated their traffic via Facebook. These last, which backed the Labour leader Jeremy Corbyn unreservedly, enjoyed particular success during the 2017 general election campaign. Their online reach among younger voters during that campaign may have exceeded that of the established mainstream press.

New entrants are overwhelmingly digital, but in print media the free Metro and small-scale print publications such as the anti-Brexit weekly the New European (owned by Archant Media) - have also meant that UK media are more pluralistic than ever before. Some new players are not transparent about their ownership and do not always choose to join a regulator. Neither Sputnik nor Breitbart provide any channel for readers to make a complaint about their reporting, apart from an online contact form on the Sputnik page, and neither are members of a press regulation body. Social media also presents a new set of challenges to democratic debate (see Chapter 3.4).

Journalists have been gloomy about the decline of paid-for news contents and its adverse implications for the health of media outlets and the ability of the press to report freely. Freedom House identified 'varied ways in which pressure can be placed on the flow of objective information and the ability of platforms to operate freely and without fear of repercussions'. They rated the UK's media environment as 'free' in 2017, giving it an overall score of 25 (where 0 denotes the most free and 100 the least). This represents a four-point worsening in the UK's score since 2013. Although Freedom House considers the UK's press 'largely open', significant concerns about regulation and government surveillance are unresolved.

\section{Press regulation and the Crime and Courts Act}

Poor or inaccurate media reporting (especially by the press) may generate a great deal of misery for the people involved. UK newspapers maintained for many years a very weak apparatus of 'self-regulation', which collapsed in the wake of a major scandal about reporters at the News of the World, Daily Mirror and other tabloid titles 'hacking' the phones of celebrities and politicians so as to uncover aspects of their private lives. This was always a criminal activity, but Scotland Yard proved strangely reluctant to act until long after the large scale of scandal became apparent. In 2014, the BBC's sensationalist live reporting of the search of singer Cliff Richard's home as part of an investigation into allegations of sexual offences, featuring helicopter shots of a police raid, was apparently based on police leaks. With the case later dismissed, it proved controversial, and the Corporation eventually had sizeable damages and legal costs awarded against it for invading Richard's privacy, in a court judgment that some critics argued would constrain future press freedom.

The phone-hacking scandal produced a long-delayed Inquiry into the Culture, Practices and Ethics of the Press chaired by Lord Leveson. It deemed the previous Press Complaints Commission 'not fit for purpose' and it was dissolved. But Leveson's call for 
an independent, self-regulatory body to create and uphold a new standards code for the media failed to get press cooperation. The only government-created (but independently appointed) Press Recognition Panel (PRP) is Impress, which regulates over 100 small, chiefly local and digital publications. Most national newspapers have joined the Independent Press Standards Organisation (Ipso). However, the Financial Times and the Guardian chose to set up their own internal mechanisms for handling complaints, citing worries about Ipso's independence and the royal charter model that underpins it. The charter is not a statute but is drafted and approved by the Privy Council, which its critics argue amounts to 'unacceptable political involvement' in press regulation.

To try and make publishers join a PRP-approved regulator, section 40 of the coalition government's Crime and Courts Act 2013 gave those that have done so the opportunity to settle libel action through a low-cost arbitration scheme. If they did not, they may be liable for the claimant's costs in libel, privacy or harassment cases. The vast majority of the press have vociferously opposed the implementation of section 40, with the Financial Times opening its objections by claiming that the press landscape had been 'utterly transformed' since the publication of the Leveson report. Index on Censorship warned that section 40 'protects the rich and powerful and is a gift to the corrupt and conniving to silence investigative journalists - particularly media outfits that don't have very deep pockets'. In March 2018 the responsible minister announced that section 40 would be repealed, and the previously proposed second part of the Levenson inquiry scrapped - leaving the shape, let alone the effectiveness, of any future press regulation or self-regulation unclear.

\section{Libel law and 'gag' orders}

For decades the English law of libel has provided for potentially large damages against anyone publishing statements likely to lower the reputation of the claimant in the eyes of reasonable people, even if the statements were true. Papers also had to prove that 'defamatory' statements were not maliciously motivated. The Defamation Act 2013 simplified the so-called 'Reynolds defence' against libel by codifying it more simply: if a statement is in the public interest and the writer reasonably believes it to be so, it enjoys protection. In addition, a libel claimant must prove the statement caused 'serious' harm. English PEN and Index on Censorship both welcomed the overhaul: 'England's notorious libel laws [have been] changed in favour of free speech', said the latter. The number of defamation cases fell to around 60 in the three years 2014-16. A growing proportion of these related to social media postings by private individuals.

English law also allows for 'gag' injunctions preventing publication of details (like names) if the subject can claim their privacy would be damaged. In recent years these have declined greatly, because such information can easily be published by third parties online, and court proceedings made public, thus undermining the very purpose of the action. The privacy injunction remains a tool of the rich: 'With average legal fees of $£ 400$ an hour, the first court hearing would cost up to $£ 100,000$,' reported the Guardian in 2016. For almost all citizens, pre-emptive action against breaches of privacy is out of the question, and post-hoc privacy actions are likewise impossible. Self-regulation and effective means of redress therefore take on an even greater importance. 


\section{Leaking of government secrets and a proposed Espionage Act}

The UK government operates a system (called D notices) where the responsible minister can exceptionally bar papers or broadcasters from running items that would endanger a clear national interest (for example, publishing the names of UK espionage agents). UK journalists have been vigilant in keeping such cases to an absolute minimum. However, other developments have changed the picture a lot.

In 2013, the American IT contractor Edward Snowden passed large amounts of classified material from the US National Security Agency (NSA) to the Guardian and Washington Post which revealed details of government surveillance programmes, also involving GCHQ (the UK's electronic surveillance agency). GCHQ requested the Guardian to handover its copy of the material. Instead, warned that the security services were considering taking legal action to halt its reporting, the paper destroyed the hard drives and memory chips with cutting tools at their offices. This was 'a largely symbolic act' the paper said, because the same files were stored in other jurisdictions.

As a result, the Law Commission, a normally neutral, expert legal body, undertook a review of the Official Secrets Act, and recommended its replacement with a modernised Espionage Act in 2016. The proposals immediately created fears that they would criminalise receiving and handling any data that the government deems damaging to national security, even if editors and journalists were merely examining leaked material. The influential Open Rights Group described the new provisions as a 'full-frontal attack on journalism.... The intention is to stop the public from ever knowing that any secret agency has ever broken the law.' However, the Commission's 'public consultation' was badly mishandled, and its publicity was even worse. The proposals were sent back for more work, initially planned for autumn 2017 and then postponed to September 2018. The Commission insists on its website that under its proposals:

'An offence is only committed if the defendant "knew or had reasonable grounds to believe his or her conduct was capable of benefitting a foreign power and intended or was reckless as to whether his or her conduct would prejudice the safety or interests of the state". Currently someone can commit an offence under the Official Secrets Act 1911 even if he or she thought their conduct was in the interests of the UK.'

\section{Re-establishing trust}

While trust in the BBC's ability to deliver accurate and reliable news remains high (70\%), trust in journalists in the UK overall remains much lower than in most of the EU and USA. It is lower still among under-35s and those who describe themselves as left-wing. Among journalists themselves, most say owners, advertising and profit considerations have little influence over their work. A quarter of them believe that it is sometimes justifiable to publish unverified information.

However, fact-checking has become an increasingly common practice online, pioneered by the charity FullFact, and later adopted by the BBC, Channel 4 and Guardian. Google's 
Digital News Initiative is currently looking at ways to automate parts of the process. Mindful of how Donald Trump's presidency came about and has developed, the media industry is beginning to grapple with the question of how to report untrue or contested statements made by top politicians.

\section{Conclusions}

The media system is changing fast, and it is often easy to lament all change as a decline from a past golden age, and to resent 'new goods' that are having disruptive effects. Optimists, on the other hand, argue that the choice and variety of news information available to Britons have never been greater and that press and broadcasters are free from censorship or direct government interference.

Pessimists see a largely unreconstructed national press, wedded to truth-bending, high intensity partisanship, with unregulated power concentrated in the hands of a few press barons (often pushing their corporate agendas as well business interest), and a wider profession resistant to any meaningful professionalism or effective self-policing of journalistic practices. In the wings, UK government and official sources have proposed restrictive laws that would greatly inhibit journalistic enterprise and ability to investigate especially where the UK's still-large 'secret state' operates, largely immune to any public or parliamentary scrutiny.

Ros Taylor (@rosamundmtaylor) is Research Manager at the LSE Truth, Trust and Technology Commission and co-editor of LSE Brexit. She is a former Guardian journalist and has also worked for the BBC. 